\title{
Anti-TNF therapy and malignancy - A critical review
}

\author{
Roger B Cohen $\mathrm{MD}^{1}$, Karen A Dittrich $\mathrm{PhD}^{2}$
}

\begin{abstract}
RB Cohen, KA Dittrich. Anti-TNF therapy and malignancy A critical review. Can J Gastroenterol 2001;15(6):376-384. The roles of tumour necrosis factor (TNF) and anti-TNF therapy in malignancy are reviewed, including an overview of baseline risk factors for malignancy in inflammatory diseases and the incidences of malignancies observed in clinical trials of an antiTNF- $\alpha$ therapy, infliximab. The preclinical data and early clinical experience presented for infliximab do not provide evidence for a causal relationship between TNF- $\alpha$ antagonism and the development of lymphoid or nonlymphoid cancers.
\end{abstract}

Key Words: Anti-tumour necrosis factor; Cancer; Crohn's disease; Etanercept; Infliximab; Lymphoma; Malignancy; Rheumatoid arthritis

$\mathrm{T}$ umour necrosis factor (TNF) $-\alpha$ is a cytokine that exhibits a wide spectrum of activities, with TNF receptors found on virtually all cell types examined. The natural functions of TNF- $\alpha$ are thought to include modulation of host immune and inflammatory response to a variety of infectious, malignant and autoimmune conditions as part of a complex regulatory mechanism in which many other cytokines participate. While initial TNF- $\alpha$ expression in response to infection or injury would be considered beneficial, excessive production, typically by activated monocytes and macrophages, can produce significant pathological changes (1). TNF- $\alpha$ has been implicated as the primary mediator in bacterial sepsis and appears to play a role in a number of chronic inflammatory disorders, including rheumatoid arthritis and Crohn's disease.

\section{Traitement anti-TNF et néoplasie, revue critique}

Le rôle du facteur de nécrose tumorale ou TNF (pour tumour necrosis factor) et du traitement anti-TNF dans la néoplasie sont passés en revus, y compris un survol des facteurs de risque de base de néoplasie dans la maladie inflammatoire et les incidences de néoplasie observées lors d'essais cliniques sur l'anti-TNF- $\alpha$ infliximab. Les données précliniques et les données cliniques préliminaires présentées pour l'infliximab ne fournissent pas de preuve d'un lien de cause à effet entre l'antagonisme du TNF- $\alpha$ et le développement des cancers lymphoïdes ou non lymphoïdes.

${ }^{1}$ Fox Chase Cancer Center, Philadelphia, and ${ }^{2}$ Centocor Inc, Malvern, Pennsylvania, USA

Correspondence and reprints: Dr Roger B Cohen, Department of Medical Oncology, Fox Chase Cancer Center, 7701 Burholme Avenue,

Philadelphia, Pennsylvania 19111-2412, USA. Telephone 215-214-1676, fax 215-728-3639, e-mail RB_Cohen@fccc.edu

Received for publication July 13, 2000. Accepted April 3, 2001 
decreased immunogenicity and optimum antibody effector functioning within the human immune system. The final infliximab antibody possesses a glycosylated IgG1 structure with an approximate molecular weight of 150,000 Da and the pharmacokinetic characteristics of a human Ig (1-3). Infliximab binds to soluble TNF- $\alpha$ and transmembrane TNF- $\alpha$ with high affinity (association constant, Ka, of $10^{10} \mathrm{M}^{-1}$ ). By binding to TNF- $\alpha$, infliximab blocks the interaction of TNF- $\alpha$ with its receptors and thereby prevents the deleterious effects caused by excessive TNF- $\alpha$ production. Infliximab does not neutralize TNF- $\beta$ (lymphotoxin-alpha), a related cytokine that uses the same receptors as TNF- $\alpha$ (2). TNF- $\alpha$ initiates signalling by crosslinking TNF receptors present in the cell membrane. The therapeutic benefit of infliximab is likely due, in part, to a blockade of TNF- $\alpha$-mediated cellular events by preventing the association of TNF- $\alpha$ with its receptors (1-3).

Throughout preclinical and clinical development, infliximab has demonstrated an excellent safety profile. However, given that this agent neutralizes TNF- $\alpha$, a key cytokine in host immune surveillance, the potential impact of infliximab treatment on the development of infections, autoimmunity and malignancy must be monitored. The effects of infliximab treatment on the development of infections and autoimmunity have recently been described (4). The present paper provides the most up to date compendium of preclinical and clinical data regarding infliximab treatment and malignancy.

The clinical information on infliximab presented throughout this article derives from a seven-year-long clinical trials program sponsored by Centocor Inc. Studies in this program included a prospective three-year post-treatment follow-up of all patients. Among the 912 patients treated in the 12 infliximab clinical trials to date, 770 were treated with infliximab and 192 were treated with placebo; 142 patients were treated with placebo only and 50 patients were treated initially with placebo and subsequently with infliximab. All of the placebo-treated patients and 653 of the infliximab-treated patients were enrolled in randomized, controlled studies (5-11). The majority of patients were treated in trials of either Crohn's disease or rheumatoid arthritis. The single largest clinical experience is based on the Anti-TNF Trial in Rheumatoid Arthritis with Concomitant Therapy (ATTRACT) study, a randomized, controlled study of rheumatoid arthritis that enrolled 428 patients (8). A small number of patients were treated in an ulcerative colitis trial or compassionate use study. The 770 infliximab-treated patients comprised 556 patients with rheumatoid arthritis, 202 patients with Crohn's disease, 10 patients with ulcerative colitis and two patients with multiple sclerosis.

\section{TNF- $\alpha$ IN MALIGNANCY: HISTORICAL PERSPECTIVE}

TNF- $\alpha$ activity was first detected over 100 years ago because of its ability to kill certain tumour cells (hence the name tumour necrosis factor) and induce fever, anorexia and cachexia in animal studies (12). TNF- $\alpha$ is a cytokine produced in vivo by activated macrophages and monocytes, with multiple effects on normal and malignant cells. Ultimately, the net effects of TNF- $\alpha$ may be either beneficial or injurious to the host depending on the level of TNF- $\alpha$. At low physiological levels, TNF- $\alpha$ functions primarily to orchestrate an effective immune response (13) and plays an important role in conjunction with lymphotoxin in the development and function of normal lymphoid tissue (14). In addition, as a cytolytic molecule produced by cytotoxic $\mathrm{T}$ lymphocytes and natural killer (NK) cells, TNF- $\alpha$, along with lymphotoxin and NK cytotoxic factor, is a component of the cell-mediated immune response that lyses tumour cells (15).

Established consequences of TNF- $\alpha$ overproduction are inflammatory diseases such as rheumatoid arthritis and Crohn's disease. Also, during overwhelming bacterial infection, the acute overproduction of TNF- $\alpha$ contributes to septic shock syndrome characterized by hypotension, organ failure and death (16). Interestingly, recent research has indicated that elevated levels of TNF- $\alpha$ may contribute to the pathogenesis of cancers (see further discussion below in 'Could Anti-TNF- $\alpha$ Therapy Cause Cancer?') (17-22).

Although in vitro studies in cell cultures and in vivo studies in animal models have demonstrated the antitumour capacities of TNF- $\alpha$, early clinical trials quickly showed that the systemic administration of TNF- $\alpha$ induced severe side effects, mainly due to its varied action on immunocompetent cells $(23,24)$. In addition, early clinical trials with TNF- $\alpha$ for the treatment of cancer have failed to reveal clinically relevant antineoplastic activity in cancer patients (25).

\section{COULD ANTI-TNF- $\alpha$ THERAPY CAUSE CANCER?}

Due to TNF- $\alpha$ 's role as a cytolytic factor in in vitro and in vivo models of tumour surveillance $(15,23)$, there has been a concern that anti-TNF- $\alpha$ therapy might increase the likelihood of tumour development. However, there is much evidence to refute this supposition, as outlined below.

TNF- $\alpha$ knockout mice: The data from TNF- $\alpha$ and TNF receptor (TNFr) knockout mice are contradictory. Most experiments do not suggest any adverse effects on antitumour host defense caused by knockout of the cytokine or its receptor.

In one published model, the responses of lymphokineactivated NK cells in TNF- $\alpha$ knockout mice were impaired in vitro and cytotoxicity was restored by in vivo administration of recombinant TNF- $\alpha$ to the mice (26). These mice also failed to reject transplanted syngeneic sarcomas, and rejection was restored by administration of recombinant TNF- $\alpha$. There was no reported increase, however, in spontaneous tumour development in these experiments.

In contrast, recent published experiments by three other groups using TNF knockout mice suggest the very opposite effects of eliminating the cytokine and/or its receptor. Thus, in transgenic mice deficient in their ability to produce 

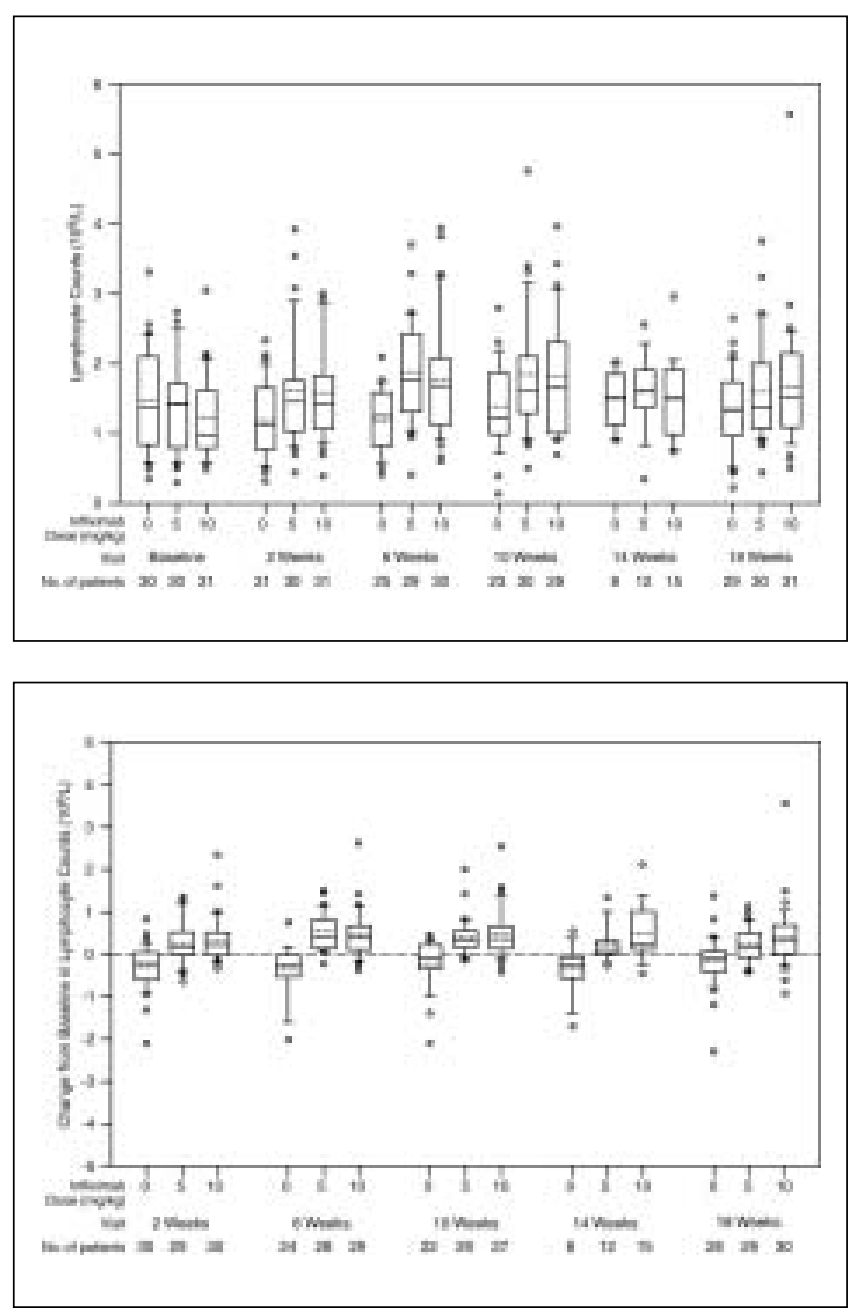

Figure 1) Box plots of lymphocyte counts from baseline through week 18 (top) and change in lymphocyte counts through week 18 (bottom) from a placebo controlled, repeated dose study of infliximab in the treatment of 94 patients with enterocutaneous fistula as a complication of Crohn's disease. Patients were treated at zero, two and six weeks with placebo $(\mathrm{n}=31), 5 \mathrm{mg} / \mathrm{kg}$ infliximab $(\mathrm{n}=31)$ or $10 \mathrm{mg} / \mathrm{kg}$ infliximab $(n=32)$. The top and bottom of each box indicate the 25 th and 75 th percentiles. The solid line within the box denotes the median; the mean is denoted by a dotted line. The central vertical lines (whiskers) extend from the edge of the box to the 10th and 90th percentiles. Any value exceeding these percentiles is represented with an open circle

TNF- $\alpha$ or the TNFr (TNF- $\alpha$ or TNFr knockout mice), no increase in spontaneous tumour development was reported (27-29). Indeed, in two models of skin carcinogenesis $(27,29)$, TNF- $\alpha$ knockout mice were actually resistant to the development of both benign and malignant tumours induced by repeated doses of 7,12-dimethylbenz[a]anthracene (DMBA) or induced by DMBA and promoted by 12 O-tetradecanoyl-phorbol-13-acetate.

TNF $-\alpha$ in the pathogenesis of cancer: Numerous studies have indicated that cytokines such as TNF- $\alpha$ may contribute to the pathogenesis of cancers $(17,18)$. The possible mechanisms include promotion of cell growth and inhibition of apoptosis (17). Indeed, it is clear that TNF- $\alpha$ can function as a growth factor for hairy cell leukemia cells $(19,20)$ and that antagonism of TNF- $\alpha$ action can lower tumour burden in this disease (21). TNF- $\alpha$ may also play a role in the bone remodelling disturbances that characterize hairy cell leukemia (30) and may be a progression factor for $B$ cell leukemia (22). In addition, elevated levels of TNF- $\alpha$ have been found to allow malignant cells to escape immune surveillance through inhibition of protein tyrosine phosphatase activity, resulting in diminished expression of the major histocompatability complex class I antigen on the cell surface (18). Finally, in vitro selection of a cell line for resistance to lysis by TNF- $\alpha$ selects for reduced as opposed to increased tumorigenicity (31).

Infliximab does not suppress general immune function: Anti-TNF- $\alpha$ therapy in human beings does not alter the number or function of cells potentially involved in tumour surveillance, including T cells, NK cells, B cells, monocytes and macrophages. In the infliximab clinical trial programs in patients with Crohn's disease and rheumatoid arthritis, studies conducted to determine the effects of infliximab treatment on general immune function included white blood cell count analyses, mitogen and recall antigen proliferative responses of peripheral blood mononuclear cells, and multitest cell-mediated immunity skin tests. Results of these analyses indicated that infliximab does not cause a generalized suppression of the immune system function in these patients. Instead, a modest increase in lymphocyte counts and increased $\mathrm{T}$ cell proliferative responses to certain recall antigens suggest that TNF- $\alpha$ antagonism may promote the transition to a more normal immune profile $(32,33)$. Lymphocyte counts (actual values and changes from baseline) following treatment with infliximab in patients with fistulizing Crohn's disease are provided in Figure 1 . These data, representative of other infliximab trials of both Crohn's disease and rheumatoid arthritis, illustrate that lymphocyte counts do not change in patients treated with infliximab relative to those of patients treated with placebo (Centocor Inc, data on file). Anti-TNF- $\alpha$ therapies also do not appear to alter the number of specific $T$ cell subsets $(34,35)$.

Specific inhibition of TNF- $\alpha$ but not lymphotoxin- $\alpha$ : As described previously, lymphotoxin-alpha (TNF- $\beta$ ) is a component of the cell-mediated immune response that lyses tumour cells. Agents that are specific only to TNF- $\alpha$ and that do not crossreact with lymphotoxin-alpha, retain the anti-inflammatory benefits of anti-TNF- $\alpha$ therapy while avoiding any potential tumorigenic complications from inhibiting lymphotoxin-alpha. Infliximab treatment does not inhibit lymphotoxin activity (2).

\section{RISK FACTORS FOR MALIGNANCY IN INFLAMMATORY DISEASES}

Little is known about the mechanisms that drive tumour promotion and progression in humans. However, inflammatory processes appear to play a role. The association between inflammation and cancer has been observed in many different tissues. One of the most compelling examples is chronic gastritis caused by Helicobacter pylori. This persistent inflammation of the stomach can result in the 
TABLE 1

A summary of published population-based studies in patients with rheumatoid arthritis

\begin{tabular}{|c|c|c|c|c|c|c|}
\hline Study, year (reference) & location (if applicable) & End point & $\begin{array}{c}\text { Years of } \\
\text { follow-up }\end{array}$ & $\begin{array}{c}\text { Number of } \\
\text { rheumatoid } \\
\text { arthritis patients }\end{array}$ & $\begin{array}{c}\text { All cancers } \\
\text { (observed versus } \\
\text { expected) }\end{array}$ & $\begin{array}{c}\text { Lymphomas } \\
\text { (observed } \\
\text { versus expected) }\end{array}$ \\
\hline Monson and Hall, 1976 (47) & & Mortality & 42 & 1035 & 1.36 & 1.71 \\
\hline Isomaki et al, 1978 (48) & Finland & Incidence & 7 & 46,101 & 1.06 & 2.7 \\
\hline Allebeck, 1982 (49) & & Mortality & 7 & 1165 & 1.14 & 1.9 \\
\hline Katusic et al, 1985 (46) & Mayo Clinic & Incidence & 34 & 521 & 0.98 & 1.2 \\
\hline Prior, 1985 (50) & $\begin{array}{l}\text { Birmingham, } \\
\text { United Kingdom }\end{array}$ & Incidence & 19 & 489 & 1.35 & 20.0 \\
\hline Laakso et al, 1986 (51) & Finland & Mortality & 10 & 1000 & 0.72 & 3.5 \\
\hline Gridley et al, 1993 (45) & Sweden & Incidence & 20 & 11,683 & $0.95(0.9-1.0)$ & $2.38(1.5-3.6)$ \\
\hline Mellemkjaer et al, 1996 (50) & Denmark & Incidence & 14 & 20,699 & $1.08(1.03-1.13)$ & $2.4(1.9-2.9)$ \\
\hline Wolfe, 1994 (53) & $\begin{array}{l}\text { United States } \\
\text { and Canada }\end{array}$ & Mortality & 35 & 3501 & 0.339 & $8.016^{*}$ \\
\hline
\end{tabular}

*Lymphoma and leukemia

eventual development of low- or high-grade lymphoma of the mucosa-associated lymphoid tissue, which can be cured in some early cases by eradication of the $H$ pylori with antibiotic therapy $(36,37)$. Other examples of induction of cancer by chronic inflammation include schistosomiasis (a common parasitic disease) leading to bladder cancer (38), the development of squamous cell cancer in scar tissue (39) and the development of colorectal cancer in patients with ulcerative colitis (40). Rheumatoid arthritis and Crohn's disease are both characterized by chronic inflammation, which could theoretically promote the development of cancer in otherwise healthy individuals (41-44). Further details on these latter associations are provided in the sections that follow.

Rheumatoid arthritis: Despite long-standing antigenic stimulation, patients with rheumatoid arthritis do not experience an increased incidence of all types of cancer (45). There is a widely acknowledged association, however, between rheumatoid arthritis and lymphomas. This conclusion is based on numerous cohort and case-control studies spanning a 25-year period (45-53). Current debate focuses on the precise magnitude of risk and identification of risk factors for lymphoma development in patients with rheumatoid arthritis. The factors that appear to be predictive of lymphoma risk are the duration of disease (longer duration resulting in increased risk) (41,42), severity (more intense inflammation resulting in increased risk) (54) and treatment of the disease (especially with broad-spectrum immunosuppressants such as methotrexate and azathioprine) (55). The current consensus is that there is at least a two- to threefold increase in the risk of developing a lymphoma associated with rheumatoid arthritis, independent of any additional risk that may be the result of immunosuppressive therapies such as methotrexate and azathioprine $(45,46,48-50,56)$. The association appears to be strongest for non-Hodgkin's lymphoma (NHL), including low- and high-grade disease $(45-53)$. Any associations with multiple myeloma $(46,48,50,51,57)$ and acute myelogenous leukemia (46,48-51) are much weaker.

The largest published cohort studies in patients with rheumatoid arthritis are summarized in Table 1. Some cohorts included patients from a particular hospital, region or clinic $(46,47,49,50,53)$. Others, such as the large Nordic studies, reflect national population data $(45,48,51,52)$. In each case, the authors calculated standardized incidence ratios for NHL and other diseases. The ratios were adjusted for sex, age, calendar year and type of cancer. The studies show, with one exception (46), a consistent increase in NHL risk among patients with rheumatoid arthritis, particularly in the larger studies from Finland (48), Sweden (45) and Denmark (52), in which the relative risk for NHL development lies between 2 and 3. It is noteworthy, with only one exception, that the incidence of all cancers was not significantly increased in any of these studies, suggesting that the rheumatoid arthritis population is uniquely susceptible to the development of lymphoma.

A number of case-control studies have indicated that the duration and severity of disease are related to lymphoma risk in patients with rheumatoid arthritis. Both of these factors may be quite relevant to the cases described in the infliximab clinical trials (see 'Incidence of solid tumours for infliximab therapy' and 'Incidence of lymphomas for infliximab therapy' below), because this study population consisted of individuals with severe disease of long duration. Data from a subset of the Swedish cohort for example, suggest an increased risk for patients with the most severe disease (45). Based on these preliminary findings, Baecklund et al (54) performed a nested case-control study of Swedish patients with rheumatoid arthritis and demonstrated that the odds ratio for NHL was as high as 25.8 for patients with high compared with low inflammatory activity, regardless of drug treatment. Data of this type may provide an additional 
argument for the use of pharmacological agents to reduce inflammatory disease activity - not only to prevent joint damage but possibly to protect against the subsequent development of lymphoma.

The type of medicinal treatment may be an additional risk factor, as described in two recent studies that examined the potential for contemporary immunosuppressive therapy, particularly methotrexate and azathioprine, to increase lymphoma risk. In a matched cohort study, Jones et al (55) compared a unique population in Wichita, Kansas that was not exposed to immunosuppressive drugs with patients in the United Kingdom who had been exposed to drugs such as azathioprine. A relative risk of 6 for 'neoplasm of the immune system' was observed for the immunosuppressiveexposed population. In a similar type of matched case-control study using the Arthritis, Rheumatism and Aging Medical Information System (ARAMIS) database, a North American rheumatoid arthritis registry, Williams et al (58) observed odds ratios for NHL of 5 and 1.7 for patients treated with azathioprine and methotrexate, respectively.

Crohn's disease: Patients with Crohn's disease appear to be at risk for the development of intestinal adenocarcinoma (59). Extraintestinal lymphomas, including NHL and Hodgkin's disease (HD), are not common in patients with Crohn's disease, although there is a well documented association in some (but not all) studies between Crohn's disease and intestinal lymphoma $(60,61)$. A review of the medical literature reveals $28 \mathrm{NHL}$ and nine $\mathrm{HD}$ cases in which Crohn's disease either preceded a diagnosis of lymphoma or was discovered simultaneously. In most of these cases, the lymphoma arose at an intestinal site, providing evidence for a correlation with inflammation.

It is unclear whether patients with Crohn's disease are at a higher risk for developing lymphoma, but several factors suggest that they might be. Patients with Crohn's disease have a chronically activated and abnormal immune system. During their illness, they often receive numerous immunosuppressive therapies, including prednisone and azathioprine, as well as increased exposure to ionizing radiation through diagnostic radiographs. The use of immunosuppressive drugs, particularly azathioprine, has a clear association with the development of NHL in other clinical settings, including rheumatoid arthritis and solid organ transplantation $(53,55,58,62,63)$. Additionally, in experiments designed to study the putative agent(s) related to Crohn's disease, athymic mice were injected with mesenteric lymph node homogenates from four patients with active Crohn's disease. These mice developed generalized lymphadenopathy due to lymphoma 10 to 28 weeks after the injection, suggesting that a transmissible factor present in lymph nodes of patients with Crohn's disease can cause lymphoma in athymic mice (64).

A number of observational studies have been performed in attempts to clarify the association between Crohn's disease and lymphoma, but have arrived at conflicting or inconclusive results. In an inception cohort of 216 patients with Crohn's disease followed in Olmsted County,
Minnesota, one case of primary small bowel lymphoma occurred, yielding a standardized incidence ratio of 2.4, but the confidence intervals did not exclude the value of one because of the small numbers of patients (65). In the St Marks series of 755 patients with inflammatory bowel disease (450 with Crohn's disease) treated with azathioprine, there was no increase in NHL risk (57). A Swedish population-based cohort of 1655 patients with Crohn's disease included a single case of lymphoma and derived a standardized incidence ratio for lymphoma of 0.4 (no excess risk) (66).

The one small population-based study that reported a relative risk for NHL of 9.8 in men with inflammatory bowel disease did not separate patients with ulcerative colitis from those with Crohn's disease (67). Several referral series have been published suggesting an increased incidence of lymphoma in Crohn's disease. Thus, in a series of 396 patients with Crohn's disease treated with 6-mercaptopurine/azathioprine, there was a single case of lymphoma (68). Gyde et al (69) described a referral population of 513 patients with a twofold increased incidence of reticuloendothelial cancer. Analysis of a hospital-based referral population of 1480 consecutive cases of Crohn's disease by Greenstein et al (70) revealed four extraintestinal lymphomas. More recently, an administrative database study found that the two-year incidence rate of lymphoproliferative malignancies among 4008 hospitalized patients with Crohn's disease in California was 5.2 cases/1000 patients with Crohn's disease, again suggesting an increased risk of lymphoma (71). Of note, two of the 21 incident cases were $\mathrm{HD}$, which is now considered a form of B cell lymphoma (72). The tendency of referral series to mislead by overestimating the incidence of rare diseases such as lymphoma is well known (73). The small numbers of lymphomas in each of the published referral or population-based series make any association difficult to prove or refute. Thus, one must conclude that a relationship between lymphoma development and Crohn's disease remains uncertain.

\section{INCIDENCE OF MALIGNANCIES IN CLINICAL TRIALS OF ANTI-TNF THERAPY}

The information presented in subsequent sections of this article derives from validated data reported during the study or during the three-year prospective follow-up period, as of December 2000. A large number of patients continue to be monitored in the three-year prospective safety follow-up study. Incidences are reported only for validated data for which patient-years could be calculated. Spontaneously reported malignancies beyond the prospective three-year follow-up period are not included, because these reports are not validated and corresponding patient-years of follow-up have not been obtained for the total patient cohort.

As mentioned above, the infliximab clinical trial experience for the reporting of malignancies includes the 770 infliximab-treated patients and 192 patients treated with placebo who participated in the infliximab clinical trials, accounting for 1898 and 295.6 patient-years of follow-up, 
TABLE 2

Number of patients with non-lymphoma malignancies in all infliximab studies* and expected rates according to the National Institutes of Health Surveillance, Epidemiology, and End Results

\begin{tabular}{|c|c|c|c|c|c|c|}
\hline & \multicolumn{3}{|c|}{ Placebo } & \multicolumn{3}{|c|}{ Infliximab } \\
\hline & $\begin{array}{l}\text { Patient-years } \\
\text { of follow-up }\end{array}$ & $\begin{array}{l}\text { Observed number } \\
\text { of cancer cases }\end{array}$ & $\begin{array}{c}\text { Expected } \\
\text { number } \\
\text { of cancer cases }\end{array}$ & $\begin{array}{l}\text { Patient-years } \\
\text { of follow-up }\end{array}$ & $\begin{array}{c}\text { Observed } \\
\text { number } \\
\text { of cancer cases }\end{array}$ & $\begin{array}{c}\text { Expected } \\
\text { number } \\
\text { of cancer cases }\end{array}$ \\
\hline Nonmelanoma skin cancers & 295.6 & 1 & $\mathrm{NA}^{+}$ & 1898.1 & 8 & $\mathrm{NA}^{+}$ \\
\hline Other malignancies & 295.6 & $2^{\ddagger}$ & 1.51 & 1898.1 & $12^{\S}$ & 11.23 \\
\hline
\end{tabular}

*Includes all follow-up data in any locked database, during both the study and long term follow-up through three years after the last infusion; ${ }^{\dagger}$ The Surveillance, Epidemiology and End Results database does not track nonmelanoma skin cancers; therefore comparison of the incidences of nonmelanoma skin cancer in the infliximab trials to the expected incidence in a matched healthy population is not available (NA); ${ }^{\ddagger}$ Placebo patients: one with spindle cell carcinoma (Crohn's disease), one with kidney disease (Crohn's disease); \$Infliximab patients: four with melanoma (rheumatoid arthritis), one with myeloma (rheumatoid arthritis), two with breast cancer (rheumatoid arthritis), one with rectal cancer (rheumatoid arthritis), one with lung cancer (rheumatoid arthritis), one with thyroid cancer (Crohn's disease), one with colon cancer (Crohn's disease), one with prostate cancer (Crohn's disease)

respectively. It is significant to note that virtually all of the patients treated in infliximab clinical trials were receiving some type of immunosuppressive therapy, such as glucocorticoids, azathioprine, 6-mercaptopurine or methotrexate, or had received them in the past.

Among patients enrolled in the infliximab clinical trials and followed prospectively for three years, the following cases of malignancy were observed: 14 solid tumours (12 in infliximab-treated and two in placebo-treated patients), four lymphomas (all in infliximab-treated patients) and nine nonmelanoma skin cancers (eight in infliximabtreated patients and one in a placebo-treated patient).

Interestingly, similar incidences in malignancy were reported during clinical trials of another anti-TNF agent, etanercept (Enbrel; Immunex, USA). Etanercept is a dimeric fusion protein (comprising the extracellular ligandbinding portion of the human p75 TNF receptor linked to the Fc portion of human IgG1) that is approved for the treatment of patients with rheumatoid arthritis. In a long term safety trial of etanercept in the treatment of rheumatoid arthritis that is refractory to disease-modifying antirheumatic drugs, nine malignancies of various types were reported during observation of the 782 patients evaluated for periods of up to 33 months (representing 890 patientyears of follow-up) (74). The incidence of cancer in the etanercept and infliximab clinical trials was similar. Any comparison between these two agents, however, is clearly constrained by the relatively small numbers of patients treated with each agent, the limited duration of follow-up and the inability to match the two treated populations for key baseline characteristics.

Further details of the malignancies observed in patients enrolled in infliximab trials are presented in the following sections.

Incidence of solid tumours and nonmelanoma skin cancers in clinical trials of infliximab therapy: In all infliximab clinical trials and excluding nonmelanoma skin cancers, 12 infliximab-treated and two placebo-treated patients developed solid tumours during the studies or dur- ing the three-year prospective follow-up period. This corresponds to incidences of 0.0063 and 0.0068 per patient-year for infliximab-treated and placebo-treated patients, respectively. As shown in Table 2, the observed number of solid tumours is similar to the expected number of solid tumours in a healthy cohort of individuals from the National Institutes of Health Surveillance, Epidemiology, and End Results (SEER) database who were matched for age, sex and duration of follow-up. Because the SEER database is based on normal subjects, the expected incidence of solid tumours likely represents a conservative estimate for chronically ill populations of patients with diseases such as rheumatoid arthritis and Crohn's disease.

The incidence of nonmelanoma skin cancers is also similar in infliximab-and placebo-treated patients $(0.0042$ versus 0.0034 per patient-year, respectively). The SEER database does not track nonmelanoma skin cancers; therefore comparison of the incidences of nonmelanoma skin cancer in the infliximab trials with the expected incidence in a matched healthy population is not available.

Incidence of lymphomas in clinical trials of infliximab therapy: Among the 770 infliximab-treated patients and 192 patients treated with placebo who participated in the infliximab clinical trials, one infliximab-treated patient with Crohn's disease and three infliximab-treated patients with rheumatoid arthritis developed a lymphoma (NHL or HD) either during the clinical trial or during the three-year follow-up period (Table 3). Based on the available data, the incidence of lymphoma in infliximab-treated patients is 0.0021 per patient-year. As discussed above, patients with chronic inflammatory diseases such as rheumatoid arthritis are at a significantly increased risk of developing lymphoproliferative disorders. Therefore, a comparison of the incidence of lymphoproliferative disorders in infliximab-treated patients with that of a healthy population is probably not informative.

A summary of infliximab-treated patients who developed lymphomas is provided in Table 3, and further discussion of these patients is provided below. None of the cases 
TABLE 3

A summary of infliximab-treated patients with lymphoproliferative malignancies

\begin{tabular}{|c|c|c|c|c|c|}
\hline $\begin{array}{l}\text { Patient } \\
\text { demographics }\end{array}$ & $\begin{array}{l}\text { Prior/concomitant } \\
\text { immunosuppressant } \\
\text { therapy }\end{array}$ & $\begin{array}{l}\text { Infliximab dose } \\
\text { (number of } \\
\text { infusions) }\end{array}$ & $\begin{array}{c}\text { Type of } \\
\text { malignancy }\end{array}$ & $\begin{array}{l}\text { Time from } \\
\text { last infliximab } \\
\text { infusion }\end{array}$ & $\begin{array}{l}\text { Additional } \\
\text { information }\end{array}$ \\
\hline $\begin{array}{l}\text { 74-year-old woman with } \\
\text { RA for } 36 \text { years }\end{array}$ & Prednisone, methotrexate & $10 \mathrm{mg} / \mathrm{kg}(8)$ & B cell lymphoma & 2 months & None \\
\hline $\begin{array}{l}\text { 48-year-old man } \\
\text { with RA for } 16 \text { years }\end{array}$ & $\begin{array}{c}\text { Azathioprine, prednisone, } \\
\text { methotrexate }\end{array}$ & $10 \mathrm{mg} / \mathrm{kg}(2)$ & B cell NHL & 18 months & $\begin{array}{c}12 \text { years of } \\
\text { lymphadenopathy, } \\
\text { baseline axillary } \\
\text { node enlargement }\end{array}$ \\
\hline $\begin{array}{l}\text { 61-year-old man with } \\
\text { RA for } 16 \text { years }\end{array}$ & Methotrexate & $1 \mathrm{mg} / \mathrm{kg}(1)$ & Hodgkin's disease & 6.5 months & Baseline splenomegaly \\
\hline $\begin{array}{l}\text { 61-year-old man with } \\
\text { Crohn's disease for } 30 \text { years }\end{array}$ & Azathioprine, prednisone & $10 \mathrm{mg} / \mathrm{kg}(1)$ & B cell NHL & 8 months & Baseline lymphopenia \\
\hline
\end{tabular}

NHL Non-Hodgkin's lymphoma; RA Rheumatoid arthritis

of B cell lymphomas involved the central nervous system (CNS), and all but one (an intravascular lymphoma arising in a gastric polyp in a patient with extensive Crohn's disease) presented as nodal disease (Centocor Inc, data on file). This contrasts with the typical presentation of lymphoproliferative diseases associated with broad-spectrum immunosuppression or acquired immunodeficiency syndrome, which often are extranodal and may involve the CNS.

In the three patients with rheumatoid arthritis who developed lymphomas during and for three years following the infliximab clinical trials, their diseases included two B cell lymphomas and one case of HD. All of these patients had a long history of disease activity (ranging from five to 36 years) and had histories of prior treatment with immunosuppressive agents. In addition, two of these patients (one with HD and one with B cell NHL) had abnormalities of the lymphopoietic system (splenic enlargement and nodal enlargement, respectively) retrospectively noted at baseline, suggesting that the disease may have been present at enrolment (Centocor Inc, data on file).

A single patient with Crohn's disease developed B cell lymphoma eight months after receiving a single infusion of infliximab. This patient had lymphopenia at baseline, again suggesting a significant immunological derangement at study enrolment, as well as a 30-year history of Crohn's disease, and extended treatment with immunosuppressive agents (eight years of prednisone and six years of azathioprine). Thus, in approximately 200 infliximab-treated patients with Crohn's disease (representing approximately 600 patient-years of follow-up for all patients evaluated with Crohn's disease), one patient developed a lymphoma (Centocor Inc, data on file).

In the case of the patients with rheumatoid arthritis and the patient with Crohn's disease, B cell malignancy arose on a background of severe disease and long-standing immune suppression with agents known to be associated with a higher risk of immune system neoplasm. This information, taken together with the typical nodal presentation of the diseases (Table 3), suggests that these cases of malignancy are likely to be associated with risks inherent in the underlying diseases, and do not reflect the effects of a broad-spectrum immunosuppressant such as azathioprine (75-77).

\section{CONCLUSIONS}

We have provided an analysis of the association between anti-TNF- $\alpha$ therapy and a possible increase in solid tumour and lymphoma development. At this time the database remains relatively small. Furthermore, the studies were clearly not powered to detect any causal relationship between anti-TNF- $\alpha$ therapy and a relatively rare event such as cancer. Analysis of the available data, however, does not provide evidence for a causal relationship. In fact, certain animal data suggest that suppression of TNF may actually protect against tumour development. In addition, clinical trial data have shown that anti-TNF- $\alpha$ therapy with infliximab does not change the number or function in vitro of cells of the immune system in contrast to other conventional immunosuppressive therapies. Furthermore, an extensive analysis of data surrounding infliximab-treated patients who developed malignancies indicated that the lymphoid malignancies rarely occurred and were invariably in patients with predisposing factors for malignancies such as NHL, including long standing inflammatory disease, severe disease and/or prior treatment with immunosuppressants such as azathioprine.

Together, the preclinical data and early clinical experience with infliximab do not provide evidence for a causal relationship between TNF- $\alpha$ antagonism and the development of lymphoid or nonlymphoid cancers. Our conclusions must be tempered by the fact that the randomized clinical trial database is small (including very few patients who only received placebo) and follow-up duration of all treated patients is still relatively short. Thus, all studies of this and other anti-TNF- $\alpha$ therapies possess limited power to detect a significant difference in malignancy incidence between patients receiving placebo and those receiving 
anti-TNF- $\alpha$ therapies. Data on larger numbers of patients followed long term are needed to establish the risk of cancer more accurately.

ACKNOWLEDGEMENTS: The authors thank Thomas F Schaible PhD and Kimberly DeWoody $\mathrm{PhD}$ at Centocor, Inc, Malvern, Pennsylvania, USA, for providing data and statistical analyses from the infliximab clinical trials program and for review of this article.

\section{REFERENCES}

1. Siegel SA, Shealy DJ, Nakada MT, et al. The mouse/human chimeric monoclonal antibody cA2 neutralizes TNF in vitro and protects transgenic mice from cachexia and TNF lethality in vivo. Cytokine 1995;7:26-38.

2. Knight DM, Trinh H, Le J, Siegel SA, Shealy DJ. Construction and initial characterization of a mouse-human chimeric anti-TNF antibody. Mol Immunol 1993;30:1443-53.

3. Scallon BJ, Moore MA, Trinh H, Knight DM, Ghrayeb J. Chimeric anti-TNF- $\alpha$ monoclonal antibody cA2 binds recombinant transmembrane TNF- $\alpha$ and activates immune effector functions. Cytokine 1995;7:251-9.

4. Schaible TF. Long term safety of infliximab. Can J Gastroenterol 2000;14(Suppl C):29C-32C.

5. Elliott MJ, Maini RN, Feldman M, et al. Randomised double-blind comparison of chimeric monoclonal antibody to tumour necrosis factor alpha (cA2) versus placebo in rheumatoid arthritis. Lancet 1994;344:1105-10.

6. Kavanaugh A, St Clair EW, McCune WJ, et al. Chimeric anti-tumor necrosis factor-alpha monoclonal antibody treatment of patients with rheumatoid arthritis receiving methotrexate therapy. J Rheumatol 2000;27:841-50.

7. Maini RN, Breedveld FC, Kalden JR, et al. Therapeutic efficacy of multiple intravenous infusions of anti-tumor necrosis factor alpha antibody combined with low-dose weekly methotrexate in rheumatoid arthritis. Arthritis Rheum 1998;41:1552-63.

8. Maini RN, St Clair EW, Breedveld F, et al. Infliximab (chimeric antitumor necrosis factor alpha monoclonal antibody) versus placebo in rheumatoid arthritis patients receiving concomitant methotrexate: a randomised phase III trial. ATTRACT Study Group. Lancet 1999;354:1932-9.

9. Targan SR, Hanauer SB, van Deventer SJ, et al. A short-term study of chimeric monoclonal antibody cA2 to tumor necrosis factor alpha for Crohn's disease. Crohn's disease cA2 study group. N Engl J Med 1997;337:1029-35.

10. Present DH, Rutgeerts $P$, Targan $S$, et al. Infliximab for the treatment of fistulas in patients with Crohn's disease. N Engl J Med 1999;340:1398-405.

11. Sands B, Podolsky D, et al. Chimeric monoclonal anti-tumor necrosis factor antibody (cA2) in the treatment of severe steroid refractory ulcerative colitis. Gastroenterology 1996;110:A65-4.

12. Beutler B. Tumor Necrosis Factors: The Molecules and Their Emerging Role in Medicine. New York: Raven Press, Ltd, 1992.

13. Remick DG, Kunkel SL. Pathophysiologic alterations induced by tumor necrosis factor. Int Rev Exp Pathol 1993;34:7-25.

14. Smyth MJ, Johnstone RW, Cretney E, et al. Multiple deficiencies underlie NK cell inactivity in lymphotoxin- $\alpha$ gene-targeted mice. J Immunol 1999;163:1350-3.

15. Arancia G, Malorni W, Donelli G. Cellular mechanisms of lymphocyte-mediated lysis of tumor cells. Ann Ist Super Sanita 1990;26:369-84.

16. Tracey KJ, Cerami A. Tumor necrosis factor and regulation of metabolism in infection: role of systemic versus tissue levels. Proc Soc Exp Biol Med 1992;200:233-9.

17. Montserrat E. Chronic lymphoproliferative disorders. Curr Opin Oncol 1997;9:34-41.

18. Holden RJ, Pakula IS, Mooney PA. An immunological model connecting the pathogenesis of stress, depression, and carcinoma. Med Hypoth 1998;51:309-14.

19. Barak V, Nisman B, Polliak A. The tumor necrosis factor family and correlation with disease activity and response to treatment in hairy cell leukemia. Eur J Haematol 1999;62:71-5.
20. Schiller JH, Bittner G, Spriggs DR. Tumor necrosis factor, but not other hematopoietic growth factors, prolongs the survival of hairy cell leukemia cells. Leuk Res 1992;16:337-46.

21. Huang D, Reittie JE, Stephens S, Hoffbrand AV, Brenner MK. Effects of anti-TNF monoclonal antibody infusion in patients with hairy cell leukemia. Br J Haematol 1992;81:231-4.

22. Foa R, Massaia M, Cardona S, et al. Production of tumor necrosis factor-alpha by B-cell chronic lymphocytic leukemia cells: a possible regulatory role of TNF in the progression of the disease. Blood 1990;76:393-400.

23. Mueller H. Tumor necrosis factor as an antineoplastic agent: pitfalls and promises. Cell Mol Life Sci 1998;54:1291-8.

24. Hieber U, Heim ME. Tumor necrosis factor for the treatment of malignancies. Oncology 1994;51:142-53.

25. Schleuning M, Munker R. Tumor necrosis factor: an update on basic research and clinical applications. Klin Wochenschr 1990;68:841-6.

26. Baxevanis CN, Voutsas IF, Tsitsilonis OE, et al. Compromised antitumor responses in tumor necrosis factor alpha knockout mice. Eur J Immunol 2000:30:1957-66.

27. Douni E, Akasssoglou K, Alexopoulou L, et al. Transgenic and knockout analysis of the role of TNF in immune regulation and disease pathogenesis. J Inflamm 1995-96;47:27-38.

28. Marino MW, Dunn A, Grail D, et al. Characterization of tumor necrosis factor-deficient mice. Proc Natl Acad Sci USA 1997;94:8093-8.

29. Moore RJ, Owens DM, Stamp G, et al. Tumor necrosis factor-[alpha] deficient mice are resistant to skin carcinogenesis. Nat Med 1999;5:828-31.

30. Demeter J. Production of tumor necrosis factor-alpha by B-cell chronic lymphocytic leukemia and hairy cell leukemia cells: considerations regarding bone remodeling in the chronic B-cell leukemias. Blood 1991;75:1127-8. (Lett)

31. Patek PQ, Lin Y. In vitro selection of a cell line for resistance to lysis by tumor necrosis factor-alpha selects for reduced tumorigenicity. J Immunol 1991;146:3457-61.

32. Cope AP, Londei M, Chu R, et al. Chronic exposure to tumor necrosis factor (TNF) in vitro impairs the activation of T cells through the $\mathrm{T}$ cell receptor/CD3 complex; reversal in vivo by antiTNF antibodies in patients with rheumatoid arthritis. J Clin Invest 1994;94:749-60.

33. D'Haens GD, Ceuppens J, Colpaert S, Rutgeerts P. Restoration of decreased in vitro lymphocyte proliferative response to mycobacteria and mitogens after a single infusion of chimeric anti-TNF $\alpha$ antibodies in Crohn's disease. Gastroenterology 1997;112:A959.

34. Meenan J, Hommes DW, Dullemen H, et al. The influence of the $\mathrm{TNF} \alpha \mathrm{mAb}$ cA2 on circulating lymphocyte populations. Gastroenterology 1997:122:A1039.

35. Feldmann M, Elliott MJ, Woody JN, Maini RN. Anti-tumor necrosis factor-alpha therapy of rheumatoid arthritis. Adv Immunol 1997;64:283-350.

36. Parsonnet J, Hansen S, Rodriguez L, et al. Helicobacter pylori infection and gastric lymphoma. N Engl J Med 1994;330:1267-71.

37. Wotherspoon AC, Doglioni C, Diss TC, et al. Regression of primary low-grade B-cell gastric lymphoma of mucosa-associated lymphoid tissue type after eradication of Helicobacter pylori. Lancet 1993;342:575-7.

38. Rosin MP, Anwar WA, Ward AJ. Inflammation, chromosomal instability, and cancer: the schistosomiasis model. Cancer Res 1994;54:1929s-33s.

39. Cruickshank AH, McConnell EM, Miller DG. Malignancy in scars, chronic ulcers, and sinuses. J Clin Pathol 1963;16:573-80.

40. MacDougall PM. The cancer risk in patient with ulcerative colitis. Lancet 1966;ii:655-8.

41. Symmons DP, Ahern M, Bacon PA, et al. Lymphoproliferative malignancy in rheumatoid arthritis: a study of 20 cases. Ann Rheum Dis 1984;43:132-5.

42. Symmons DP. Neoplasia in rheumatoid arthritis. J Rheumatol 1988;15:1319-22.

43. Porter D, Madhok R, Capell H. Non-Hodgkin's lymphoma in rheumatoid arthritis. Ann Rheum Dis 1991;50:275-6.

44. Logan RF, Rifkind EA Turner ID, Ferguson A. Mortality in celiac disease. Gastroenterology 1989;97:265-71.

45. Gridley G, McLaughlin JK, Ekbom A, et al. Incidence of cancer among patients with rheumatoid arthritis. J Natl Cancer Inst 1993;85:307-11.

46. Katusic S, Beard CM, Kurland LT, Weis JW, Bergstralh E. Occurrence of malignant neoplasms in the Rochester, Minnesota, rheumatoid arthritis cohort. Am J Med 1985;78:50-5. 
47 Monson RR, Hall AP. Mortality among arthritics. J Chron Dis 1976;29:459-67.

48. Isomaki HA, Hakulinen T, Joutsenlahti U. Excess risk of lymphomas, leukemia and myeloma in patients with rheumatoid arthritis. J Chron Dis 1978;31:691-6.

49. Allebeck P. Increased mortality in rheumatoid arthritis. Scand J Rheumatol 1982;11:81-6.

50. Prior P. Cancer and rheumatoid arthritis: epidemiologic considerations. Am J Med 1985;78:15-21.

51. Laakso M, Mutru O, Isomaki H, Koota K. Cancer mortality in patients with rheumatoid arthritis. J Rheumatol 1986;13:522-6.

52. Mellemkjaer L, Linet MS, Gridley G, Frisch M, Moller H, Olsen JH. Rheumatoid arthritis and cancer risk. Eur J Cancer 1996;32A:1753-7.

53. Wolfe F, Mitchell DM, Sibley JT, et al. The mortality of rheumatoid arthritis. Arthritis Rheum 1994;37:481-94.

54. Baecklund E, Ekbom A, Sparén P, Feltelius N, Klareskog L. Disease activity and risk of lymphoma in patients with rheumatoid arthritis: nested case-control study. Br Med J 1998;317:180-1.

55. Jones M, Symmons D, Finn J, Wolfe F. Does exposure to immunosuppressive therapy increase the 10-year malignancy and mortality risks in RA? Matched cohort study. Br J Rheum 1996;35:738-45

56. Silman AJ, Petrie J, Hazleman B, Evans SJ. Lymphoproliferative cancer and other malignancy in patients with rheumatoid arthritis treated with azathioprine: a 20-year follow up study. Ann Rheum Dis 1988;47:988-92.

57. Kelly C, Sykes H. Rheumatoid arthritis, malignancy, and paraproteins. Ann Rheum Dis 1990;49:657-9.

58. Williams CA, Bloch DA, Sibley J, Haga M, Wolfe F, Raynauld JP. Lymphoma and leukemia in rheumatoid arthritis: are they associated with azathioprine, cyclophosphamide, or methotrexate? A matched case-control study in the Arthritis, Rheumatism and Aging Medical Information System (ARAMIS) population. J Clin Rheumatol 1996;2:64-72.

59. Bernstein D, Rogers A. Malignancy in Crohn's disease. Am J Gastroenterol 1996;91:434-40.

60. Caspi O, Polliack A, Klar R, Ben-Yehuda D. The association of inflammatory bowel disease and leukemia - coincidence or not? Leuk Lymphoma 1995;17:255-62.

61. Connell WR, Kamm MA, Dickson M, Balkwill AM, Ritchie JK, Lennard-Jones JE. Long-term neoplasia risk after azathioprine treatment in inflammatory bowel disease. Lancet 1994;343:1249-52.
62. Penn I. Cancers complicating organ transplantation. N Engl J Med 1990;323:1767.

63. Kinlen L. Immunosuppressive therapy and acquired immunologic disorders. Cancer Res 1992;52(Suppl):5474-6.

64. Das KM, Valenzuela I, Morecki R. Crohn disease lymph node homogenates produce murine lymphoma in athymic mice. Proc Natl Acad Sci USA 1980;77:588-92.

65. Loftus EV, Sandborn WJ, Tremaine WJ, Harmsen WS, Zinsmeister AR. Risk of lymphoma in inflammatory bowel disease: a population-based estimate. Digestive Diseases Week, May 16-22, 1998. (Abst G4195).

66. Ekbom A, Helmick, C, Zack, M, Adami H-O. Extracolonic malignancies in inflammatory bowel disease. Cancer 1991;67:2015-9.

67. Bernstein CN, Kliewer E, Rawsthorne P, Doig W, Blanchard JF. Diagnoses of extra-intestinal manifestations and cancers in IBD in large population-based databases. Gastroenterology 1998;114:A930.

68. Present DH, Meltzer SJ, Krumholtz MP, Wolke A, Korelitz BI. 6-mercaptopurine in the management of inflammatory bowel disease: short and long-term toxicity. Ann Intern Med 1989;111:641-9.

69. Gyde SN, Prior P, Macartney JC, Thompson H, Waterhouse JAH, Allan RN. Malignancy in Crohn's disease. Gut 1980;21:1024-9.

70. Greenstein AJ, Mullin GE, Strauchen JA, et al. Lymphoma in inflammatory bowel disease. Cancer 1992;69:1119-23.

71. Bickston SJ, Lichtenstein GL, Arseneau KO, Cohen RB, Cominelli F. The relationship between infliximab treatment and lymphoma in Crohn's disease. Gastroenterology 1999;117:1433-7.

72. Marafioti T, Hummel M, Foss HD, et al. Hodgkin and ReedSternberg cells represent an expansion of a single clone originating from a germinal center B-cell with functional immunoglobulin gene rearrangements but defective immunoglobulin transcription. Blood 2000;95:1443-50

73. Paltiel O, Ronen I, Polliack A, Epstein L. Two-way referral bias: evidence from a clinical audit of lymphoma in a teaching hospital. J Clin Epidemiol 1998;51:93-8

74. Moreland LM, Cohen SB, Baumgartner S, Schiff M. Long-term use of etanercept in patients with DMARD-refractory rheumatoid arthritis. Arthitis Rheum 1999;42:A1981.

75. Levine AM. Acquired immunodeficiency syndrome-related lymphoma. Blood 1992;80:8-20.

76. Penn I. The changing pattern of post-transplant malignancies. Transplant Proc 1991;23:1101-3.

77. Penn I. Cancer is a complication of severe immunosuppression. Surg Gynecol Obstet 1986;162:603-10. 


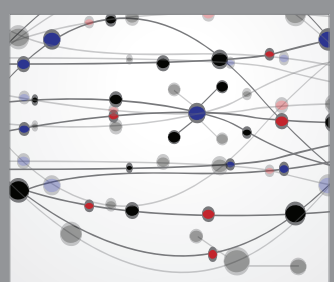

The Scientific World Journal
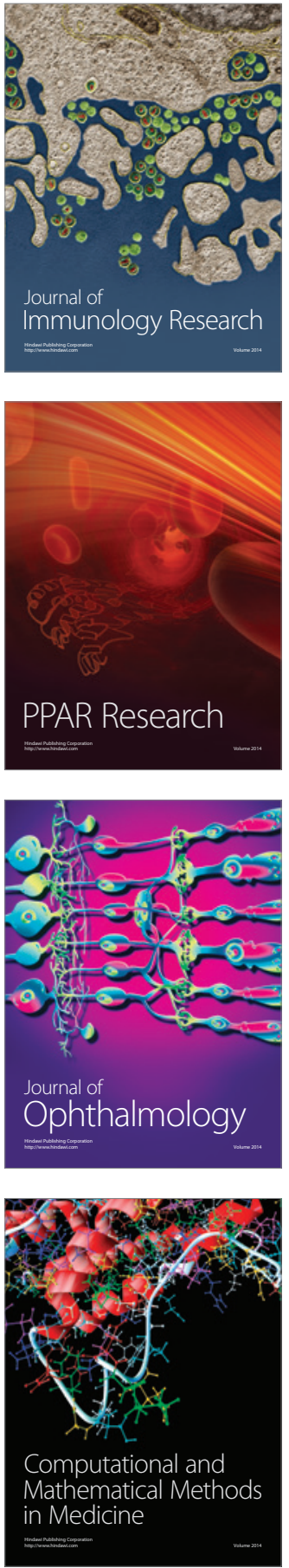

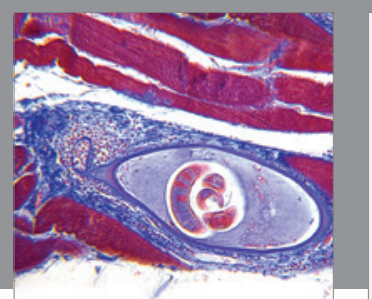

Gastroenterology Research and Practice

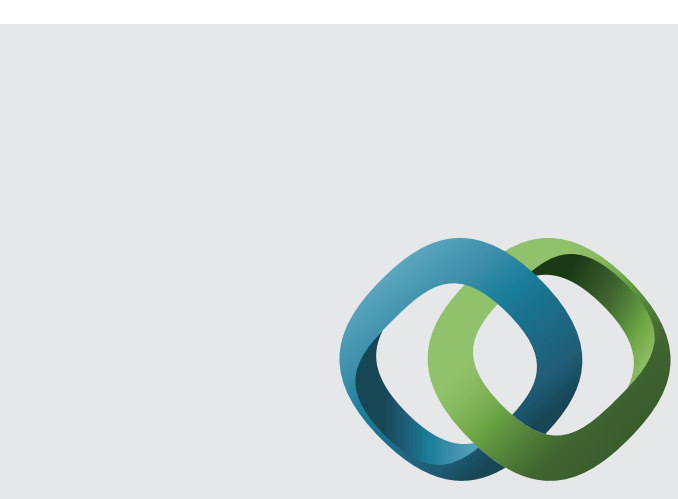

\section{Hindawi}

Submit your manuscripts at

http://www.hindawi.com
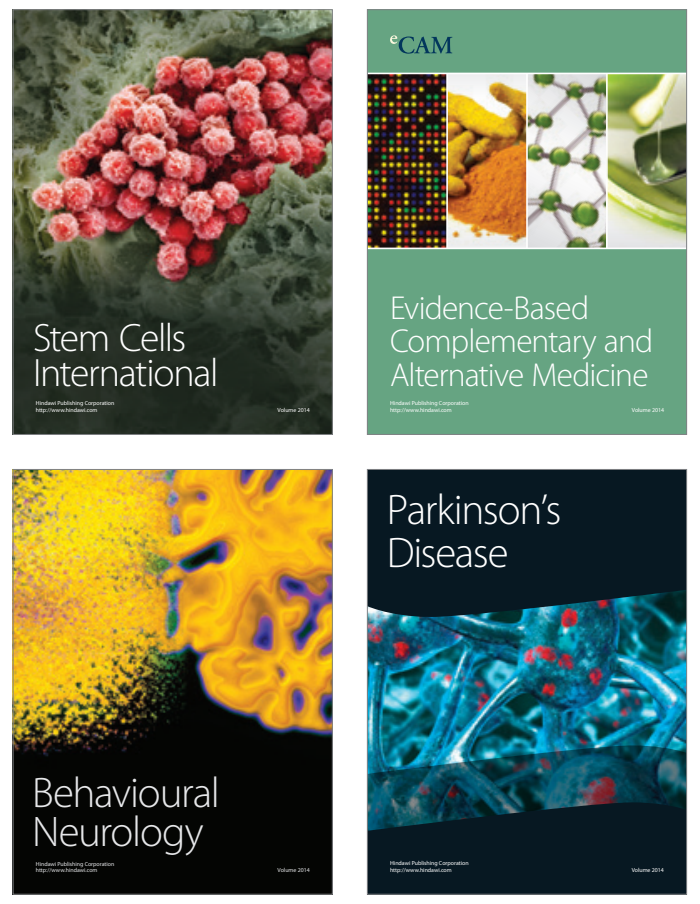
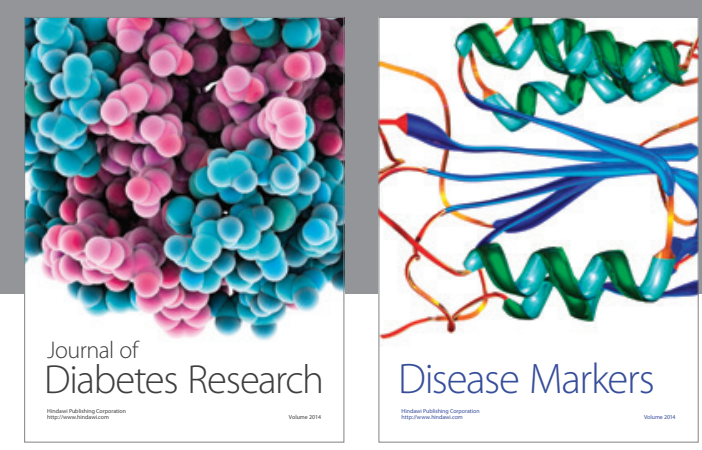

Disease Markers
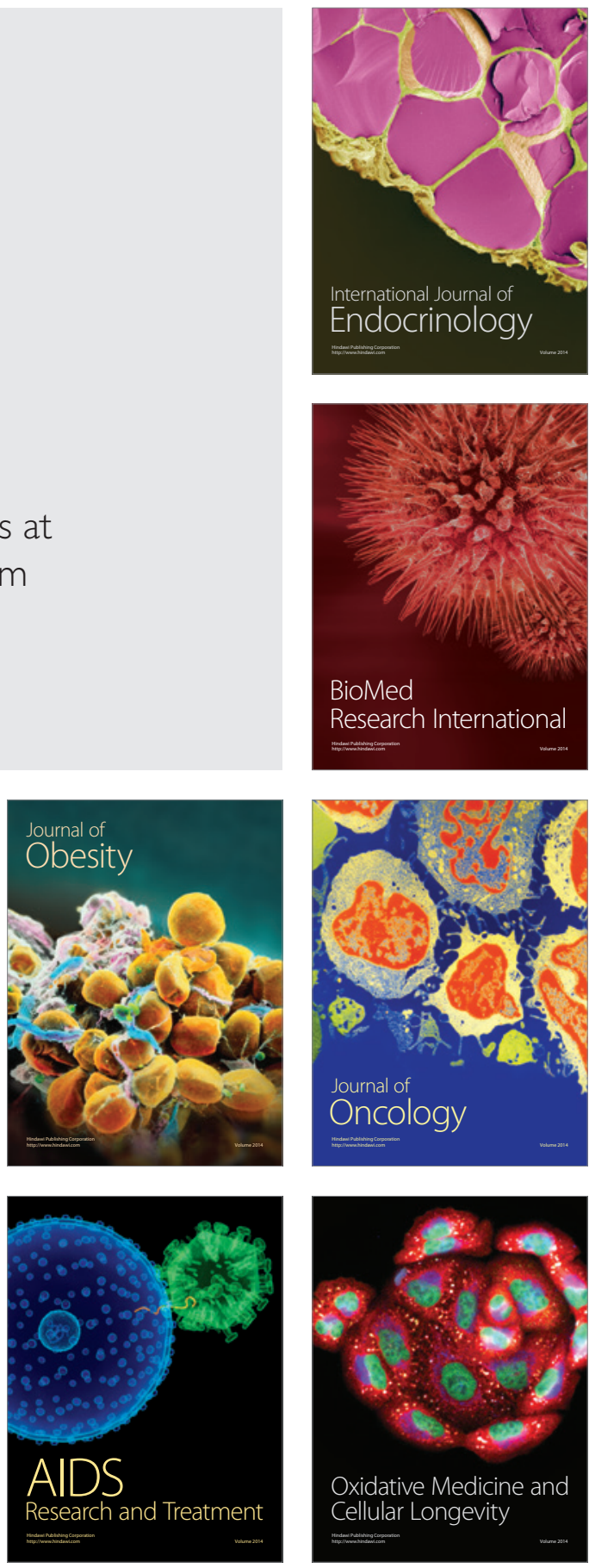